\title{
STRATEGI PENGEMBANGAN KEGIATAN KONSERVASI MANGROVE DI DESA BEDONO KABUPATEN DEMAK
}

\author{
Development Strategies of Mangrove Conservation Activities in Bedono Village Demak District
}

\author{
Reinaldi Abiyoga, Suryanti*) dan Max Rudolf Muskananfola \\ Program Studi Manajemen Sumberdaya Perairan, Departemen Sumberdaya Akuatik \\ Fakultas Perikanan dan Ilmu Kelautan, Universitas Diponegoro \\ Jl. Prof. Soedarto, SH, Tembalang, Semarang, Jawa Tengah - 50275, Telp/Fax. +6224 7474698 \\ Email : reinaldi_abiyoga@yahoo.co.id
}

\begin{abstract}
ABSTRAK
Kawasan konservasi mangrove di Desa Bedono memiliki luas \pm 300 hektar. Sebagian masyarakat memanfaatkan buah dan daun mangrove jenis Avicennia sp. untuk diolah menjadi makanan ringan. Keindahannya banyak menarik perhatian pengunjung untuk berwisata. Potensi tersebut belum dapat dikelola secara maksimal, sedangkan kegiatan konservasi mangrove yang dilakukan oleh Kelompok Mangrove Bahari sebatas melakukan penanaman mangrove, monitoring, dan penyuluhan. Alternatif strategi yang tepat dibutuhkan oleh Kelompok Mangrove Bahari supaya dapat mengembangkan kegiatan konservasi mangrove di Desa Bedono. Penelitian ini bertujuan untuk : 1.) mengetahui faktor-faktor yang mempengaruhi kegiatan konservasi mangrove; dan 2.) memperoleh alternatif strategi yang tepat untuk mengembangkan kegiatan konservasi mangrove di Desa Bedono. Metode yang digunakan dalam penelitian ini adalah metode deskripsi studi kasus. Pengambilan data dilakukan melalui wawancara, observasi, dan studi pustaka. Data yang diperoleh didiskusikan melalui fokus grup diskusi (FGD) untuk diolah dan dianalisis menggunakan analisis SWOT. Hasil analisis menunjukkan bahwa faktor-faktor yang mempengaruhi pengembangan kegiatan konservasi mangrove di Desa Bedono adalah faktor internal dan faktor eksternal. Prioritas alternatif strategi yang terpilih adalah menjaga dan meningkatkan kelestarian ekosistem mangrove, meningkatkan koordinasi dengan stakeholders, melakukan konsultasi dalam bidang ekowisata mangrove, melakukan studi banding ke objek ekowisata mangrove, dan melakukan kerjasama dengan pihak yang berkompeten dalam bidang produksi dan pemasaran produk olahan mangrove.
\end{abstract}

Kata Kunci : Mangrove, Konservasi, Pengembangan, Strategi

\begin{abstract}
The Mangrove conservation area in Bedono village covers an area of \pm 300 hectares. The people also process the fruits and leaves of mangroves of Avicennia sp. for snacks. Although the beauty of mangrove forest attract visitors, has not been optimally managed. While, the Mangrove Bahari group's conservation activities are limited to planting mangroves, monitoring, and counceling. Therefore, alternative strategies are needed for the Mangrove Bahari Group to develop mangrove conservation activities. The purpose of this study is : 1.) to determine the factors that affect mangrove conservation activities; and 2.) to obtain appropriate alternative strategies for developing mangrove conservation activities in Bedono village. The research used a descriptive case study method in which a set of interviews, observation and literature studies were adopted. SWOT analysis and a focus group discussion (FGD) with all members of Mangrove Bahari Group was applied in the formulation of development strategies. The analysis showed that the factors that influence the development of mangrove conservation activities in Bedono village are internal and external factors. The priority recommendation include the maintenance and improvement for the sustainability of mangrove ecosystems, improvement of coordination with stakeholders, consultation of management mangrove ecotourism, comparation studies of mangrove ecotourism, and cooperation of production and marketing mangrove processed products.
\end{abstract}

Keywords: Mangrove, Conservation, Development, Strategy.

*) Penulis penanggungjawab

\section{PENDAHULUAN}

Tahun 1980 terjadi konversi lahan mangrove secara besar-besaran menjadi area tambak udang yang menyebabkan rusaknya ekosistem mangrove di Desa Bedono. Penanaman bibit mangrove oleh Organization for Industrial Spiritual and Cultural Advacement (OISCA) yang dimulai pada tahun 2004 di pesisir Desa Bedono menjadi awal untuk meningkatkan kesadaran masyarakat akan pentingnya menjaga kelestarian ekosistem mangrove (Chafid, 2009). Hutan 
mangrove Desa Bedono dijadikan kawasan konservasi oleh pemerintah daerah Kabupaten Demak pada tahun 2011, melalui PERDA Nomor 6 tahun 2011 tentang Rencana Tata Ruang dan Wilayah Kabupaten Demak. Pengelolaan kawasan konservasi mangrove ini dilakukan oleh kelompok Mangrove Bahari yang bekerjasama dengan pemerintah daerah, perguruan tinggi dan OISCA. Kelompok Mangrove Bahari berencana untuk mengembangkan kegiatan konservasi mangrove di Desa Bedono, supaya kegiatan yang dilakukan bukan sekedar untuk melestarikan mangrove, tetapi juga turut menyumbang manfaat dari segi sosial dan ekonomi untuk masyarakat Desa Bedono. Kelompok Mangrove Bahari selaku pengelola kawasan konservasi mangrove Desa Bedono telah berhasil membentuk kawasan konservasi mangrove seluas \pm 300 hektar. Terbatasnya anggota menjadikan pengawasan terhadap kawasan tersebut tidak dapat dilakukan secara terus-menerus, sedangkan setiap hari kawasan tersebut dimanfaatkan oleh nelayan untuk mencari ikan, udang dan kepiting. Sebagian masyarakat yang tinggal di sekitar kawasan konservasi mangrove memanfaatkan buah dan daun mangrove (Avicennia sp.) untuk diolah menjadi manisan dan keripik, namun terkendala dalam hal produksi dan pemasaran pada produk olahan mangrove tersebut. Keindahan kawasan konservasi mangrove juga banyak menarik perhatian pengunjung baik dari dalam maupun luar Kabupaten Demak untuk berwisata, oleh karena itu banyak nelayan yang memodifikasi perahunya untuk dijadikan sebagai sarana transportasi wisatawan.

Potensi kawasan konservasi mangrove yang begitu besar belum dapat dikelola secara maksimal oleh Kelompok Mangrove Bahari. Hal ini dikarenakan kegiatan yang dilakukan oleh Kelompok Mangrove Bahari sebatas melakukan penanaman mangrove, monitoring, dan penyuluhan. Tidak adanya alternatif kegiatan yang lain membuat Kelompok Mangrove Bahari hanya berfokus pada perluasan kawasan konservasi mangrove saja. Oleh karena itu untuk mengatasi permasalahan tersebut diperlukan alternatif strategi yang tepat supaya kegiatan konservasi mangrove di Desa Bedono dapat dikembangkan dengan lebih maksimal, sehingga potensi kawasan konservasi mangrove tersebut dapat dikelola dan dimanfaatkan dengan baik. Tujuan dari kegiatan penelitian ini adalah : 1.) untuk mengetahui faktor-faktor yang mempengaruhi pengembangan kegiatan konservasi mangrove di Desa Bedono; dan 2.) memperoleh alternatif strategi yang tepat untuk mengembangkan kegiatan konservasi mangrove di Desa Bedono. Kegiatan penelitian ini dilaksanakan pada bulan Oktober-November 2016 bertempat di Desa Bedono, Kecamatan Sayung, Kabupaten Demak.

\section{MATERI DAN METODE PENELITIAN}

\section{A. Materi Penelitian}

Materi yang digunakan dalam penelitian ini adalah kegiatan konservasi mangrove yang terletak di Desa Bedono meliputi aspek sumberdaya manusia Kelompok Mangrove Bahari, kondisi kawasan konservasi mangrove, dan pemanfaatan kawasan konservasi mangrove oleh masyarakat dan pengunjung.

\section{B. Metode Penelitian}

Metode yang digunakan dalam penelitian ini adalah metode deskripsi studi kasus. Penelitian deskriptif merupakan penelitian yang dilakukan untuk menjelaskan sesuatu secara sistematis, faktual, dan actual (Nazir, 2003). Penelitian ini menggunakan dua jenis data yaitu data primer dan sekunder. Data primer diperoleh dengan melakukan survei dan observasi lapangan, sedangkan untuk data sekunder diperoleh dengan melakukan survei institusional dan studi literatur yang relevan. Institusi yang dituju untuk mendukung penelitian ini adalah institusi yang terkait dengan pengelolaan pantai dan pesisir. Studi literatur dapat diperoleh dari penelusuran tehadap dokumen penunjang yang berasal dari hasil kajian atau penelitian sebelumnya. Penentuan narasumber menggunakan metode purposive sampling yang dilakukan berdasarkan pertimbangan bahwa masyarakat Desa Bedono dan para pengunjung kawasan konservasi mangrove merupakan para pelaku yang memanfaatkan segala potensi yang ada pada ekosistem tersebut, sedangkan semua anggota Kelompok Mangrove Bahari merupakan pelaku utama dalam kegiatan konservasi mangrove di Desa Bedono, sehingga informasi yang didapatkan akan lebih akurat. Jumlah responden yang diwawancarai dalam penelitian ini berjumlah 50 orang dengan rincian 5 orang anggota kelompok mangrove bahari, 30 orang masyarakat desa bedono, dan 15 orang pengunjung.

Proses pengumpulan data dilakukan dengan wawancara dan pertanyaan yang diajukan kepada semua narasumber bersifat campuran tertutup dan terbuka untuk menggali informasi secara menyeluruh. Pertanyaan kombinasi dapat digunakan untuk menggali informasi yang lebih luas dan dalam (Herdiansyah, 2013). Informasi yang telah terkumpul kemudian dibahas dan ditentukan faktor internal dan eksternal yang berhubungan dengan pengembangan kegiatan konservasi mangrove di Desa Bedono, selanjutnya hasil didiskusikan dengan anggota kelompok Mangrove Bahari melalui fokus grup diskusi (FGD). Analisis strategi dilakukan dengan cara menilai bobot masing-masing faktor dan memilih alternatif dan prioritas strategi menggunakan analisis SWOT. Proses selanjutnya membuat sebuah perbandingan antara kondisi eksternal dan internal dalam sebuah matriks SWOT untuk menggambarkan kondisi keterkaitan masing-masing factor. Menurut Saru (2007) dalam Prayuda (2014), hasil penjabaran faktor internal dan eksternal dinilai dan dilakukan pembobotan oleh peserta FGD, kemudian dilakukan tabulasi data. Pemberian rating pada masing-masing faktor menggunakan skala likert dari angka satu sampai dengan angka empat berdasarkan besarnya pengaruh faktor tersebut. Hasil yang diperoleh digunakan untuk menentukan prioritas strategi berdasarkan urutan rangkingnya, sehingga diperoleh rumusan strategi yang jelas. 


\section{HASIL DAN PEMBAHASAN}

\section{SDM Kelompok Mangrove Bahari}

Kelompok Mangrove Bahari didirikan pada tanggal 22 Agustus tahun 2004 atas inisiasi dari OISCA melalui musyawarah desa. Tujuan awal didirikannya Kelompok Mangrove Bahari adalah untuk melakukan penanaman mangrove guna mengurangi abrasi di Desa Bedono. Kelompok Mangrove Bahari memiliki lima orang anggota terdiri dari Bapak Kharis sebagai ketua, Aslor sebagai sekretaris, Nurdinsyah sebagai bendahara, Nurrohman sebagai seksi rehabilitasi, dan Ibu Rosadah sebagai seksi pendidikan. Pembagian tugas dan wewenang Kelompok Mangrove Bahari dilakukan berdasarkan struktur organisasi yang telah disepakati bersama melalui musyawarah.

Anggota Kelompok Mangrove Bahari sangat solid dalam melakukan kegiatan penanaman, monitoring, dan penyuluhan, walaupun tidak memperoleh gaji, mereka akan mendapat upah ketika melakukan kegiatan penanaman. Sebagian besar penanaman mangrove yang dilakukan adalah program kerjasama dengan Dinas Kelautan dan Perikanan Kabupaten Demak, Kementerian Lingkungan Hidup, Perguruan Tinggi, OISCA, dan Corporate Social Responsibility (CSR) dari berbagai perusahaan, salah satunya adalah Dunlop pada tanggal 27 Agustus 2016. Kendala yang dihadapi oleh Kelompok Mangrove Bahari dalam melakukan kegiatan konservasi mangrove adalah tidak adanya acuan program kegiatan yang jelas dan mobilitas mereka yang terbatas karena pekerjaan dan kesibukan masing-masing.

\section{Kondisi Masyarakat Desa Bedono}

Mayoritas masyarakat Desa Bedono sudah memiliki pengetahuan akan pentingnya ekosistem mangrove, baik dari segi lingkungan maupun ekonomi. Sosialisasi yang dilakukan OISCA, dinas-dinas terkait, dan Kelompok Mangrove Bahari secara kontinyu membuahkan hasil yang baik. Beberapa masyarakat di dusun Tonosari dan Morosari bahkan sudah melakukan pembibitan mangrove secara mandiri, khususnya jenis Rizhopora sp., bibit mangrove yang dipelihara sebagian akan dijual dan sebagian lagi ditanam di daerah yang rawan terkena abrasi. Masyarakat Desa Bedono juga ikut berpartisipasi dalam menjaga kelestarian kawasan konservasi mangrove. Mereka akan melapor kepada Kelompok Mangrove Bahari apabila menemukan kerusakan yang terjadi pada kawasan konservasi mangrove.

\section{Pengunjung Kawasan Konsevasi Mangrove}

Pengunjung kawasan konservasi mangrove Desa Bedono berasal dari berbagai daerah, baik dari dalam maupun luar Kabupaten Demak. Mayoritas tujuan mereka mengunjungi kawasan konservasi mangrove adalah untuk berekreasi. Mereka memperoleh informasi tentang kawasan wisata konservasi mangrove melalui internet, media elektronik, media cetak, dan infromasi dari teman. Sebagian pengunjung sudah memiliki pengetahuan tentang mangrove, mereka tahu fungsi dan manfaat mangrove dari segi lingkungan. Potensi kawasan untuk dijadikan sebagai objek ekowisata dinilai sangat baik. Fasilitas wisata kawasan konservasi mangrove dinilai cukup baik sebagai objek wisata, karena sudah tersedia area jogging track mangrove, jasa transportasi, dan pemandu wisata. Namun pengunjung mengeluhkan akses jalan yang masih rusak dan belum tersedianya tempat parkir untuk bus pariwisata.

\section{Kondisi Kawasan Konservasi Mangrove Desa Bedono}

Kawasan konservasi mangrove Desa Bedono memiliki luas $\pm 300 \mathrm{Ha}$. Ada dua jenis mangrove yang tumbuh dominan pada kawasan konservasi mangrove tersebut, yaitu Avicennia sp. dan Rizhopora sp., sealin itu terdapat beberapa jenis satwa yang menghuni kawasan konservasi mangrove tersebut, seperti ikan belodok, kepiting, udang, burung kuntul, dan ular. Kawasan konservasi mangrove ini memiliki dua fasilitas, yaitu gardu pandang dan jogging track mangrove. Fasilitas tersebut merupakan bantuan yang diberikan oleh Dinas Kelautan dan Perikanan Kabupaten Demak. Akses untuk menuju kawasan konservasi mangrove hanya dapat melalui jalur laut menggunakan perahu. Bagi yang ingin mengunjungi kawasan konservasi mangrove dapat menggunakan jasa ojek perahu yang beroperasi dari pukul 08.00 WIB - pukul 16.00 WIB. Kawasan konservasi mangrove ini sudah memiliki legalitas hukum dengan adanya PERDA Kabupaten Demak Nomor 6 tahun 2011 tentang Rencana Tata Ruang dan Wilayah Kabupaten Demak. Lahan yang ditanami mangrove merupakan lahan bekas tambak dan pemukiman yang terkena abrasi dan statusnya masih milik masyarakat atau perseorangan. Setiap kegiatan penanaman yang akan dilakukan harus mendapatkan ijin dari pemilik lahan dengan cara melibatkannya dalam kegiatan penanaman dan diberi upah.

\section{Pemanfaatan Kawasan Konservasi Mangrove}

Kelompok Mangrove Bahari memperoleh pemasukan dana dari kegiatan penjualan bibit mangrove yang didapat dari kawasan konservasi, selain itu kawasan konservasi mangrove yang dikelola Kelompok Mangrove Bahari dimanfaatkan oleh masyarakat sebagai daerah untuk mencari ikan, udang dan kepiting. Masyarakat juga memanfaatkan buah dan daun Avicennia sp. untuk dijadikan sebagai makanan ringan. Buah Avicennia sp. diolah menjadi sebuah manisan dan daun yang masih muda dijadikan keripik. Olahan dari mangrove ini dijual dengan harga Rp. 1000,00 untuk manisan buah dan Rp. 2000,00 untuk keripik. Keindahan kawasan konservasi mangrove juga dimanfaatkan sebagai tempat wisata alam. Sebagian masyarakat memodifikasi dan menyewakan perahu mereka untuk sarana transportasi menuju kawasan konservasi mangrove. Daerah kawasan konservasi mangrove yang dijadikan tujuan wisata adalah Jogging Track Mangrove dan Kampung Tenggelam. Biaya perjalan pergi-pulang untuk menuju lokasi tersebut Rp. $20.000,00$ - Rp. 25. 000,00 /orang.

\section{Faktor Internal Kawasan Konservasi Mangrove}

Faktor-faktor internal yang berhubungan dengan pengembangan kegiatan konservasi mangrove Desa Bedono dijelaskan pada tabel 1 . 
Tabel 1. Bobot, Rating, dan Skor dari masing-masing Faktor Internal

\begin{tabular}{|c|c|c|c|c|}
\hline \multicolumn{2}{|r|}{ Faktor Internal } & Bobot & Rating & Skor \\
\hline \multicolumn{5}{|c|}{ Kekuatan } \\
\hline 1 & $\begin{array}{l}\text { Kelompok Mangrove Bahari mengelola hutan mangrove yang berstatus } \\
\text { sebagai kawasan konservasi. }\end{array}$ & 0,10 & 4 & 0,40 \\
\hline 2 & $\begin{array}{l}\text { Kelompok Mangrove Bahari bekerjasama dengan OISCA dalam } \\
\text { mengelola kawasan konservasi mangrove }\end{array}$ & 0,09 & 4 & 0,36 \\
\hline 3 & Kelompok Mangrove Bahari sudah memiliki legalitas. & 0,09 & 4 & 0,36 \\
\hline 4 & $\begin{array}{l}\text { Kelompok Mangrove Bahari melibatkan masyarakat dalam kegiatan } \\
\text { konservasi. }\end{array}$ & 0,09 & 4 & 0,36 \\
\hline 5 & $\begin{array}{l}\text { Kelompok Mangrove Bahari memiliki pengalaman kerjasama dengan } \\
\text { instansi pemerintah dan swasta. }\end{array}$ & 0,09 & 4 & 0,36 \\
\hline 6 & Kelompok Mangrove Bahari memiliki anggota yang solid. & 0,09 & 3 & 0,27 \\
\hline 7 & $\begin{array}{l}\text { Kelompok Mangrove Bahari mampu membentuk kawasan konservasi } \\
\text { mangrove seluas } \pm 300 \mathrm{Ha} \text {. }\end{array}$ & 0,08 & 3 & 0,24 \\
\hline 8 & $\begin{array}{l}\text { Kelompok Mangrove bahari Memiliki fasilitas untuk mendukung } \\
\text { kegiatan konservasi mangrove }\end{array}$ & 0,08 & 3 & 0,24 \\
\hline \multicolumn{5}{|c|}{ Kelemahan } \\
\hline & $\begin{array}{l}\text { Fasilitas penunjang ekowisata yang dimiliki Kelompok Mangrove } \\
\text { Bahari belum lengkap. }\end{array}$ & 0,06 & -3 & $-0,18$ \\
\hline 2 & Mobilitas anggota Kelompok Mangrove Bahari terbatas & 0,07 & -3 & $-0,21$ \\
\hline 3 & Pengawasan terhadap kawasan konservasi mangrove kurang optimal & 0,07 & -4 & $-0,28$ \\
\hline \multirow[t]{2}{*}{4} & $\begin{array}{l}\text { Kelompok mangrove bahari tidak memiliki lahan sendiri untuk ditanami } \\
\text { mangrove }\end{array}$ & 0,08 & -4 & $-0,32$ \\
\hline & Jumlah & 1,00 & & 1,6 \\
\hline
\end{tabular}

Sumber : Hasil Pengolahan Data Kuesioner 2016

\section{Faktor Eksternal Kawasan Konservasi Mangrove}

Faktor-faktor eksternal yang berhubungan dengan pengembangan kegiatan konservasi mangrove Desa Bedono dijelaskan pada tabel 2.

Tabel 2. Bobot, Rating, dan Skor dari masing-masing Faktor Eksternal.

\begin{tabular}{|c|c|c|c|}
\hline Faktor Eksternal & Bobot & Rating & Skor \\
\hline \multicolumn{4}{|l|}{ Peluang } \\
\hline 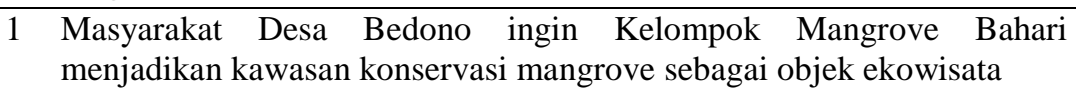 & 0,14 & 4 & 0,56 \\
\hline $\begin{array}{l}2 \text { Kawasan konservasi mangrove yang dikelola Kelompok Mangrove } \\
\text { Bahari dimanfaatkan nelayan sebagai Fishing ground }\end{array}$ & 0,13 & 4 & 0,52 \\
\hline $\begin{array}{l}3 \text { Masyarakat ingin bekerjasama dengan Kelompok Mangrove Bahari } \\
\text { untuk mengolah mangrove menjadi produk yang bernilai ekonomis. }\end{array}$ & 0,13 & 4 & 0,52 \\
\hline $\begin{array}{l}4 \text { Keterlibatan Perguruan Tinggi dalam kegiatan konservasi yang } \\
\text { dilakukan oleh Kelompok Mangrove Bahari }\end{array}$ & 0,13 & 3 & 0,39 \\
\hline $\begin{array}{l}5 \text { DKP demak bekerjasama dengan kelompok mangrove bahari dalam } \\
\text { kegiatan penyuluhan mangrove }\end{array}$ & 0,13 & 3 & 0,39 \\
\hline $\begin{array}{l}\text { Perguruan tinggi menjadikan Kelompok Mangrove Bahari sebagai mitra } \\
\text { dalam penelitian di kawasan koonservasi mangrove. }\end{array}$ & 0,13 & 3 & 0,39 \\
\hline \multicolumn{4}{|l|}{ Ancaman } \\
\hline $\begin{array}{l}\text { Pemilik ingin menjual lahan mangrove yang dikelola oleh Kelompok } \\
\text { Mangrove Bahari }\end{array}$ & 0,10 & -4 & $-0,40$ \\
\hline $\begin{array}{l}2 \text { Intervensi kelompok masyarakat dalam pengelolaan kawasan } \\
\text { konservasi }\end{array}$ & 0,11 & -4 & $-0,44$ \\
\hline Jumlah & $\mathbf{1 , 0 0}$ & & 1,93 \\
\hline
\end{tabular}

Sumber : Hasil Pengolahan Data Kuesioner 2016 


\section{Posisi strategi}

Berdasarkan analisis skor dari faktor internal dan eksternal menunjukkan bahwa posisi strategi berada pada kuadran I, yaitu strategi yang memanfaatkan kekuatan dan peluang untuk mencapai tujuan yang diinginkan. Posisi pada kuadran I menunjukkan bahwa faktor kekuatan harus dimaksimalkan supaya peluang yang sudah dimiliki dapat dimanfaatkan dengan baik. Hal ini menunjukkan bahwa pengelolaan kawasan konservasi mangrove Desa Bedono dalam kondisi yang baik dan sangat potensial untuk dikembangkan. Posisi strategi pengembangan kegiatan konservasi mangrove Desa Bedono dapat dilihat pada gambar 1.

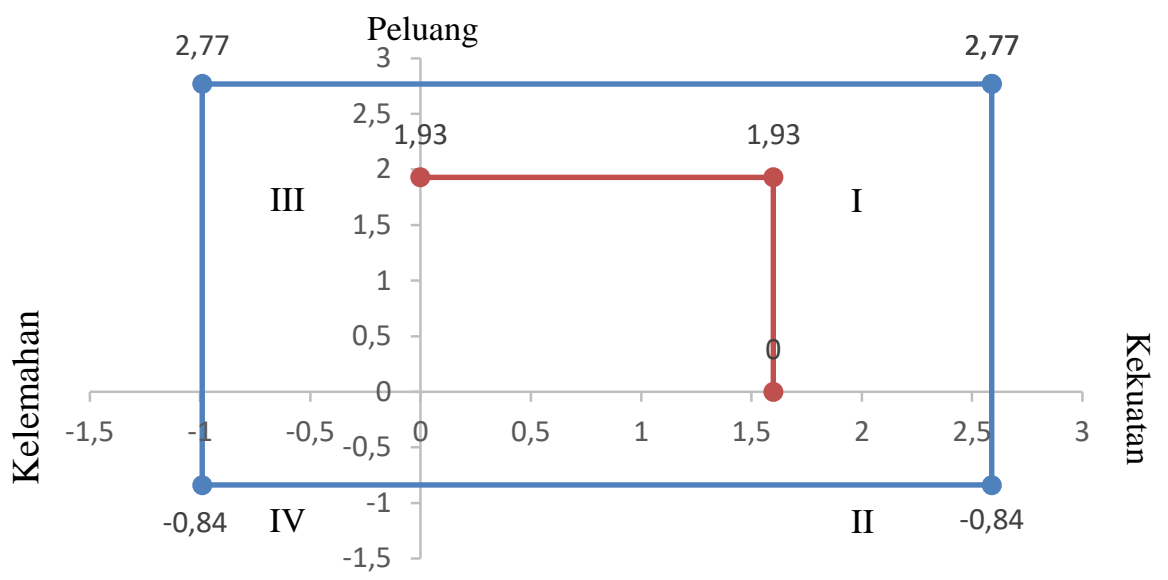

Ancaman

Gambar 1. Posisi strategi Pengembangan Kegiatan Konservasi Mangrove

\section{Perumusan strategi}

Perumusan strategi pengembangan kegiatan konservasi mangrove Desa Bedono dilakukan dengan Matriks SWOT. Faktor internal dan eksternal yang dijadikan acuan utama dalam perumusan strategi adalah kekuatan dan peluang yang dimiliki. Hal ini berdasarkan analisis posisi strategi yang telah dilakukan. Perumusan strategi pengembangan kegiatan konservasi mangrove Desa Bedono dijelaskan pada tabel 3.

Tabel 3. Perumusan Alternatif Strategi Pengembangan Kawasan Konservasi Mangrove Desa Bedono.

\begin{tabular}{|c|c|c|}
\hline Faktor Eksternal & $\begin{array}{l}\text { Kekuatan (strenght) } \\
\text { 1. Kelompok Mangrove Bahari mengelola } \\
\text { hutan mangrove yang berstatus sebagai } \\
\text { kawasan konservasi. } \\
\text { 2. Kelompok Mangrove Bahari bekerjasama } \\
\text { dengan OISCA dalam mengelola kawasan } \\
\text { konservasi mangrove } \\
\text { 3. Kelompok Mangrove Bahari sudah } \\
\text { memiliki legalitas. } \\
\text { 4. Kelompok Mangrove Bahari melibatkan } \\
\text { masyarakat dalam kegiatan konservasi. } \\
\text { 5. Kelompok Mangrove Bahari memiliki } \\
\text { pengalaman kerjasama dengan instansi } \\
\text { pemerintah dan swasta. } \\
\text { 6. Kelompok Mangrove Bahari memiliki } \\
\text { anggota yang solid. } \\
\text { 7. Kelompok Mangrove Bahari mampu } \\
\text { membentuk kawasan konservasi } \\
\text { mangrove seluas } \pm 300 \text { Ha. } \\
\text { 8. Kelompok Mangrove bahari Memiliki } \\
\text { fasilitas untuk mendukung kegiatan } \\
\text { konservasi mangrove. }\end{array}$ & $\begin{array}{ll}\text { Kelemahan (weakness) } \\
\text { 1. Fasilitas penunjang } \\
\text { ekowisata yang } \\
\text { dimiliki Kelompok } \\
\text { Mangrove Bahari } \\
\text { belum lengkap. } \\
\text { 2. } \\
\text { Mobilitas anggota } \\
\text { Kelompok Mangrove } \\
\text { Bahari terbatas } \\
\text { 3. Pengawasan terhadap } \\
\text { kawasan konservasi } \\
\text { mangrove kurang } \\
\text { optimal } \\
\text { 4. Kelompok mangrove } \\
\text { bahari tidak memiliki } \\
\text { lahan sendiri untuk } \\
\text { ditanami mangrove. }\end{array}$ \\
\hline $\begin{array}{l}\text { Peluang (opportunity) } \\
\text { 1. } \\
\text { Masyarakat Desa Bedono ingin } \\
\text { Kelompok Mangrove Bahari } \\
\text { menjadikan kawasan konservasi } \\
\text { mangrove sebagai objek ekowisata } \\
\text { 2. } \\
\text { Kawasan konservasi mangrove yang } \\
\text { dikelola Kelompok Mangrove Bahari }\end{array}$ & $\begin{array}{l}\text { Alternatif strategi (SO) } \\
\text { 1. Menjaga dan meningkatkan kelestarian } \\
\text { ekosistem mangrove. } \\
\text { 2. Meningkatkan koordinasi dengan } \\
\text { Stakeholders } \\
\text { 3. Melakukan konsultasi dengan pihak yang } \\
\text { berkompeten dalam bidang ekowisata }\end{array}$ & $\begin{array}{l}\text { Alternatif strategi (WO) } \\
\text { Memanfaatkan peluang } \\
\text { untuk meminimalikan } \\
\text { kelemahan }\end{array}$ \\
\hline
\end{tabular}


dimanfaatkan nelayan sebagai Fishing ground

3. Masyarakat ingin bekerjasama dengan Kelompok Mangrove Bahari untuk mengolah mangrove menjadi produk yang bernilai ekonomis.

4. Keterlibatan Perguruan Tinggi dalam kegiatan konservasi yang dilakukan oleh Kelompok Mangrove Bahari

5. DKP demak bekerjasama dengan kelompok mangrove bahari dalam kegiatan penyuluhan mangrove

6. Perguruan tinggi menjadikan Kelompok Mangrove Bahari sebagai mitra dalam penelitian di kawasan konservasi mangrove.

\section{Ancaman (threat)}

1. Pemilik ingin menjual lahan mangrove yang dikelola oleh Kelompok Mangrove Bahari

2. Intervensi kelompok masyarakat dalam pengelolaan kawasan konservasi mangrove.

4. Melakuakan studi banding ke kawasan konservasi/rehabilitasi mangrove yang sudah dijadikan objek ekowisata mangrove di daerah lain.

5. Melakuakan kerjasama dengan pihak yang berkompeten dalam bidang produksi dan pemasaran produk olahan mangrove.

Berdasarkan analisis menggunakan Matriks SWOT alternatif strategi yang diperoleh adalah alternatif strategi S$\mathrm{O}$ yang memaksimalkan kekuatan untuk mendapatkan peluang. Alternatif strategi tersebut adalah sebagai berikut :

1. Menjaga dan meningkatkan kelestarian ekositem mangrove

2. Meningkatkan koordinasi dengan para Stakeholders;

3. Melakukan konsultasi dengan pihak yang berkompeten dalam bidang ekowisata mangrove;

4. Melakukan studi banding ke kawasan konservasi / rehabilitasi mangrove di daerah lain; dan

5. Melakukan kerjasama dengan pihak yang berkompeten dalam bidang produksi dan pemasaran produk olahan mangrove.

\section{Penentuan Prioritas Strategi}

Alternatif strategi yang telah diperoleh digunakan untuk menentukan prioritas strategi pengembangan kegiatan konservasi mangrove Desa Bedono. Alternatif strategi yang memiliki jumlah nilai bobot terbesar dijadikan sebagai prioritas utama. Penentuan prioritas strategi pengembangan kegiatan konservasi mangrove Desa Bedono dapat dilihat pada tabel 5.

Tabel 5. Penentuan Prioritas Alternatif Strategi Pengembangan Kawasan Konservasi Mangrove Desa Bedono

\begin{tabular}{|c|c|c|c|}
\hline \begin{tabular}{|c|} 
STRATEGI S-O \\
\end{tabular} & Keterkaitan & Jumlah Skor & Ranking \\
\hline $\begin{array}{l}\text { 1. Menjaga dan meningkatkan kelestarian ekositem } \\
\text { mangrove. }\end{array}$ & $\begin{array}{l}\text { S1, S4, S6, S7, S8, O4, } \\
\text { O6 }\end{array}$ & 2,29 & $\mathrm{I}$ \\
\hline 2. Meningkatan koordinasi dengan para Stakeholders & $\mathrm{S} 2, \mathrm{~S} 3, \mathrm{~S} 4, \mathrm{~S} 5, \mathrm{~S} 7, \mathrm{O} 2$ & 2,2 & II \\
\hline $\begin{array}{l}\text { 3. Melakukan konsultasi dengan pihak yang } \\
\text { berkompeten dalam bidang ekowisata mangrove. }\end{array}$ & $\mathrm{S} 1, \mathrm{~S} 5, \mathrm{~S} 7, \mathrm{O} 1$ & 1,56 & III \\
\hline $\begin{array}{l}\text { 4. Melakukan studi banding ke kawasan konservasi / } \\
\text { rehabilitasi mangrove yang sudah dijadikan objek } \\
\text { ekowisata mangrove di daerah lain. }\end{array}$ & $\mathrm{S} 1, \mathrm{~S} 7, \mathrm{O} 1$ & 1,20 & IV \\
\hline $\begin{array}{l}\text { 5. Melakukan kerjasama dengan pihak yang } \\
\text { berkompeten dalam bidang produksi dan } \\
\text { pemasaran produk olahan mangrove }\end{array}$ & S5, S6, O3 & 1,15 & $\mathrm{~V}$ \\
\hline
\end{tabular}

Sumber : Hasil Pengolahan Data 2016

\section{a. Menjaga dan meningkatkan kelestarian ekosistem mangrove}

Kelestarian kawasan konservasi mangrove merupakan hal yang harus dijaga dan dikelola dengan baik. Mangrove bahari sebagai pengelola dan masyarakat harus saling gotong royong dalam mempertahankan kelestarian kawasan konservasi mangrove, karena hutan mangrove memiliki berbagai manfaat, khususnya untuk melindungi desa dari abrasi. Menurut Rusdianti (2012), mangrove merupakan salah satu ekosistem yang mempunyai fungsi penting sebagai pelindung gejala alam yang ditimbulkan oleh perairan, seperti abrasi, gelombang dan badai. Hal ini didukung Khaery (2016), sistem perakaran mangrove mempunyai kemampuan meredam gelombang pasang dan angin kencang, menahan lumpur dan melindungi pantai dari erosi, dan sebagai pengendali banjir.

Selain itu, kelestarian kawasan konservasi mangrove akan memberikan dampak sosial dan ekonomi bagi masyarakat, khususnya nelayan. Ekosistem mangrove yang lestari akan menarik banyak biota, seperti ikan, kepiting dan 
udang untuk menghuni kawasan tersebut, sehingga kawasan konservasi mangrove dapat dimanfaatkan oleh nelayan sebagai Fishing Ground. Menurut Madiama (2016), kawasan mangrove layak untuk diperhatikan dan diprioritaskan sebagai penunjang devisa bagi masyarakat dan negara karena secara ekologis, hutan mangrove berfungsi sebagai daerah pemijahan (Spawning Ground) dan daerah pembesaran (Nursery Ground) berbagai jenis ikan, udang, kerang-kerangan, dan lainnya.

Untuk itu, sebaiknya pengawasan terhadap kawasan konservasi mangrove perlu ditingkatkan guna mencegah kerusakan yang terjadi pada ekosistem mangrove tersebut. Pembagian wilayah pemanfaatan juga perlu dilakukan supaya daerah konservasi mangrove tetap lestari dan masyarakat tetap dapat menikmati berbagai manfaat dari ekosistem tersebut. Menurut Miswadi (2015), kawasan mangrove dapat dikembangkan melalui konsep Agroforesty dengan mengkombinasikan kegiatan kehutanan dan pertanian pada lahan yang sama. Oleh karena itu, pengelolaan ekosistem mangrove harus diarahkan supaya kegiatan eksploitasi, ekonomi, dan ekologi berjalan dengan seimbang (Purnobasuki, 2011).

\section{b. Meningkatkan koordinasi dengan para Stakeholders}

Pengembangan kegiatan konservasi mangrove Desa Bedono merupakan hal yang kompleks karena meliputi berbagai elemen yang berkepentingan di dalamnya. Perlu adanya koordinasi yang baik dari pihak Mangrove Bahari sebagai pengelola dengan masyarakat, pemerintah desa, dinas-dinas terkait, dan pihak swasta supaya pengembangan yang dilakukan bermanfaat bagi semua pihak. Menurut Kustanti (2014), sebagian besar hutan mangrove yang ada di Indonesia adalah sumberdaya milik bersama (Common Pool Resources/CPRs), sehingga perlu memperhatikan tiga aspek pengelolaan, yaitu aspek karakteristik sumberdaya, aturan main yang diterapkan, dan keterlibatan sumberdaya manusia dalam pengelolaan.

Perencanaan yang baik dengan melibatkan semua pihak diharapkan dapat memberikan dampak positif bagi pengembangan kegiatan konservasi mangrove Desa Bedono. Hal ini juga dimaksudkan untuk menghindari adanya konflik kepentingan yang berkaitan dengan pemanfaatan kawasan konservasi mangrove. Selain itu masyarakat beranggapan bahwa status lahan yang ditanami mangrove masih milik perseorangan, karena pemilik lahan yang bersangkutan masih membayar pajak kepada pemerintah. Hal ini menjadi masalah yang harus diselesaikan karena berpotensi menimbulkan konflik kepemilikan. Pendekatan aspek pertanahan perlu dilakukan supaya lahan-lahan tambak yang semula bersertifikat dan terkena abrasi segera mendapat kejelasan status kepemilikannya. Menurut pasal 27 Undang-Undang Pokok Agraria (UUPA) Nomor 5 Tahun 1960 dan Surat Menteri Negara Agraria/Kepala Badan Pertanahan Nasional (BPN) Nomor 410-1293 tanggal 9 Mei 1996 maka bidang-bidang tanah yang telah bersertifikat yang terkena abrasi dinyatakan hilang haknya atau hapus dengan sendirinya.

Konsep pengelolaan terpadu antar Stakeholders merupakan salah satu alternatif yang dapat digunakan untuk menunjang pengembangan kawasan konservasi mangrove Desa Bedono. Aksi bersama ini membutuhkan koordinasi yang baik dan matang supaya jelas fungsi dan tugas masing-masing Stakeholders. Menurut Kustanti (2016), peran Stakeholders dalam pengelolaan hutan mangrove seharusnya sesuai dengan tugas pokok dan fungsi masing-masing guna membangun kepercayaan, kebersamaan, dan pengembangan jejaring kerjasama.

\section{c. Melakukan konsultasi dengan pihak yang berkompeten dalam bidang ekowisata mangrove}

Pengembangan kawasan konservasi mangrove menjadi kawasan ekowisata mangrove merupakan pekerjaan yang tidak mudah. Untuk mengembangkan sebuah objek ekowisata mangrove, Kelompok Mangrove Bahari membutuhkan saran dan bimbingan dari pihak-pihak yang memiliki kompetensi dalam pengembangan ekowisata mangrove. Konsultasi dapat dilakukan kepada dinas pariwisata, lembaga terkait, dan kelompok masyarakat maupun perseorangan yang berkompeten di bidang ekowisata mangrove. Hal ini berguna supaya rencana pengembangan ekowisata mangrove berjalan dengan baik. Menurut Ziku (2015), masyarakat perlu berkonsultasi dan melakukan dengar pendapat dengan pihak luar guna memperoleh solusi terkait dengan pengembangan kawasan ekowisata.

Selain itu untuk mengembangkan sebuah ekowisata mangrove partisipasi masyarakat dibutuhkan dalam membantu pengelolaan dan pengawasan kawasan ekowisata. Penambahan fasilitas penunjang ekowisata seperti jogging track diperlukan supaya pengunjung dapat menikmati keindahan kawasan konservasi mangrove secara menyeluruh. Akses jalan untuk menuju lokasi ekowisata juga perlu diperbaiki untuk memudahkan pengunjung mencapai lokasi objek ekowisata. Hal ini sesuai dengan pendapat Muttaqin (2011), sebagai produk pariwisata, ekowisata harus mencakup tiga aspek seperti kegiatan pariwisata lainnya, yaitu Atraksi, Amenitas dan Aksesibilitas.

\section{d. Melakukan studi banding ke kawasan konservasi / rehabilitasi mangrove di daerah lain}

Untuk mengembangkan kualitas sumberdaya manusia dan kelembagaan usaha ekowisata mangrove diperlukan studi banding ke kawasan ekowisata mangrove yang sudah berkembang di daerah lain. Hal ini merupakan suatu upaya yang dapat dilakukan oleh Kelompok Mangrove Bahari untuk memperoleh informasi tentang model pengelolaan dan cara pengembangan kawasan ekowisata mangrove. Informasi tersebut dapat diadaptasi dan dikembangkan sesuai dengan situasi dan kondisi yang ada di kawasan konservasi mangrove Desa Bedono. Kegiatan studi banding akan memberikan pembelajaran dan pengalaman nyata terhadap hasil kegiatan yang telah dilakukan di daerah lain. Pengalaman tersebut akan menjadi modal dalam penyadaran kepada masyarakat terhadap konsep ekowisata yang akan dikembangkan. Partisipasi para stakeholders dan masyarakat sangat diperlukan untuk mendukung keberhasilan pengembangan dan pengelolaan kawasan ekowisata mangrove. Menurut Meilani dan Muntasib (2013), pengembangan ekowisata tidak akan dapat berjalan dengan baik jika hanya dilakukan oleh salah satu pihak tanpa dukungan dari pihak 
terkait lainnya. Menurut Ziku (2015), partisipasi masyarakat dalam pengembangan kawasan ekowisata dapat berupa tenaga, uang, barang, ide atau gagasan, penyedia jasa trasnportasi, menjual souvenir dan sebagai pemandu wisata.

e. Melakukan kerjasama dengan pihak yang berkompeten dalam bidang produksi dan pemasaran produk olahan mangrove

Sejauh ini hanya beberapa masyarakat Desa Bedono yang secara pribadi mengolah mangrove menjadi makanan ringan, seperti keripik dan manisan. Buah dan daun mangrove yang biasa diolah oleh masyarakat berasal dari mangrove jenis Avicennia sp. Sedikitnya masyarakat yang mengolah mangrove tidak lepas dari keterbatasan pengetahuan, kemampuan, dan fasilitas yang dimiliki. Oleh karena itu perlu dibentuk Kelompok Usaha Bersama (KUB) yang dikelola oleh masyarakat dan desa, supaya masyarakat dapat menjalin kemitraan dengan lembaga koperasi dan UMKM, sehingga produksi dan pemasaran produk olahan mangrove dapat ditingkatkan. Menurut Widyorini et al. (2015), beberapa faktor yang menyebabkan kurang berkembangnya usaha pengolahan hasil mangrove, yaitu kurangnya modal serta lemahnya daya saing produk yang dihasilkan dengan beberapa produk makanan produsen lain. Menurut Theodora et al. (2015), untuk memperluas pasar dibutuhkan promosi produk yang efektif dan tepat sasaran, salah satunya dengan membuat kemasan yang menarik.

\section{KESIMPULAN}

Kesimpulan yang diperoleh dari kegiaan penelitian ini adalah sebagai berikut :

1. Faktor internal yang berhubungan dengan pengembangan kegiatan konservasi mangrove di Desa Bedono adalah Kelompok Mangrove Bahari mengelola hutan mangrove yang berstatus sebagai kawasan konservasi, bekerjasama dengan OISCA dalam mengelola kawasan konservasi mangrove, memiliki legalitas, melibatkan masyarakat dalam kegiatan konservasi, memiliki pengalaman kerjasama dengan instansi pemerintah dan swasta, anggota yang solid, membentuk kawasan konservasi mangrove seluas $\pm 300 \mathrm{Ha}$, memiliki fasilitas untuk mendukung kegiatan konservasi mangrove, fasilitas penunjang ekowisata belum lengkap, mobilitas anggota Kelompok Mangrove Bahari terbatas, pengawasan terhadap kawasan konservasi mangrove kurang optimal, kelompok mangrove bahari tidak memiliki lahan sendiri untuk ditanami mangrove. Faktor eksternal yang berhubungan dengan pengembangan kegiatan konservasi mangrove di Desa Bedono adalah masyarakat Desa Bedono ingin membangun objek ekowisata, kawasan konservasi mangrove yang dikelola Kelompok Mangrove Bahari dimanfaatkan nelayan sebagai fishing ground, masyarakat mampu menghasilkan produk olahan dari mangrove, keterlibatan Perguruan Tinggi dalam kegiatan konservasi, DKP demak bekerjasama dengan kelompok mangrove bahari dalam kegiatan penyuluhan mangrove, perguruan tinggi menjadikan Kelompok Mangrove Bahari sebagai mitra dalam penelitian di kawasan konservasi mangrove, intervensi kelompok masyarakat dalam pengelolaan kawasan konservasi dan Pemilik lahan yang ingin menjual lahan mangrove yang dikelola oleh Kelompok Mangrove Bahari.

2. Alternatif strategi yang terpilih adalah menjaga dan meningkatkan kelestarian ekositem mangrove, meningkatkan koordinasi dengan para stakeholders, melakukan konsultasi dengan pihak yang berkompeten dalam bidang ekowisata mangrove, melakukan studi banding ke kawasan konservasi/rehabilitasi mangrove di daerah lain, dan melakukan kerjasama dengan pihak yang berkompeten dalam bidang produksi dan pemasaran produk olahan mangrove..

\section{UCAPAN TERIMAKASIH}

Ucapan Terimakasih ini penulis sampaikan kepada Drs. Ign. Boedi Hendrarto, M.Sc. Ph.D yang telah memberikan masukan dan saran untuk perbaikan jurnal ilmiah ini.

\section{DAFTAR PUSTAKA}

Chafid, M. A.dan R. Pribadi. 2009. Kajian Perubahan Luas Lahan Mangrove di Desa Bedono Kecamatan Sayung Kabupaten Demak Menggunakan Citra Satelit IkonosTahun 2004 dan 2009. Journal of Marine Research. 1 (2): $167-173$

Herdiansyah, H. 2013. Wawancara, Observasi, dan Focus Groups sebagai Instrumen Penggalian Data Kualitatif. Raja Grafindo Persada, Depok.

Khaery, A., C. Kusmana dan Y. Setiawan. 2016. Strategi Pengelolaan Ekosistem Mangrove di Desa Passare Apua Kecamatan Lantari Jaya Kabupaten Bombana Provinsi Sulawesi Tenggara. Jurnal Silvikultur Tropika. 7 (1): 38 44

Kustanti, A., B. Nugroho, D.R. Nurrochmat dan Y. Okimoto. 2014. Evolusi Hak Kepemilikan dalam Pengelolaan Ekosistem Hutan Mangrove di Lampung Mangrove Center. Risalah Kebijakan Pertanian dan Lingkungan. 1 (3): $143-158$

Madiama, S., C. Muryani dan S. Santoso. 2016. Kajian Perubahan Luas dan Pemanfaatan serta Persepsi Masyarakat terhadap Pelestarian Hutan Mangrove di Kecamatan Teluk Ambon Baguala. Jurnal Geoeco. 2 (2): 170-183 
Meilani, R. dan E. K. S. H. Muntasib. 2013. Peran Kementerian Dalam Negeri dalam Pengembangan Ekowisata di Indonesia. Media Konservasi. 18 (3): 135-141

Miswadi, H. S. Sofyan dan I. S. Yusni. 2015. Strategi Pengelolaan Pengembangan Kawasan Penyangga sebagai Hutan Cadangan Mangrove (Studi Kasus Ekosistem Mangrove Sungai Liung Kecamatan Bantan Kabupaten Bengkalis). Jurnal Dinamika Lingkungan Indonesia. 2 (2): 73-86

Muttaqin, T., R. H. Purwanto dan S. N. Rufiqo. 2011. Kajian Potensi dan Pengembangan Ekowisata di Cagar Alam Pulau Sempu Kabupaten Malang Provinsi Jawa Timur. Jurnal Penelitian Eksakta. 6 (2): 152-161

Nazir, M. 2003. Metode Penelitian. Ghalia Indonesia. Jakarta

Prayuda, E. D. 2014. Strategi Kelompok Pantai Lestari dalam Pengembangan Kegiatan Rehabilitasi Mangrove di Desa Karangsong Kabupaten Indramayu. Diponegoro Journal of Maquares. 3 (3): 80-87

Purnobasuki, H. 2011. Ancaman terhadap Hutan Mangrove di Indonesia dan Langkah Strategis Pencegahannya. Bulletin PSL Universitas Surabaya, (25) : 3-6

Rusdianti, K.dan S. Sunito. 2012. Konservasi Lahan Hutan Mangrove serta Upaya Penduduk Lokal dalam Merehabilitasi Ekosistem Mangrove. Jurnal Sosiologi Pedesaan. 6 (1): 1-17.

Sitompul, M. 2011. Kajian Pengelolaan Hutan Kemenyan (Styrax sp.) di Kabupaten Humbang Hasundutan Provinsi Sumatera Utara. [Tesis]. Program Pascasarjana Institut Pertanian Bogor. 93p

Surat Menteri Negara Agraria / Kepala Badan Pertanahan Nasional (BPN) Nomor 410-1293 tanggal 9 mei 1996 tentang Penertiban Tanah Timbul dan Tanah Reklamasi

Theodora, A., M. N. Damajanti dan C. Muljosumarto. 2015. Perancangan Media Promosi Tepung Bruguiera Mangrove di Surabaya. Jurnal DKV Adiwarna. 1 (1): 1-11

Undang-undang Nomor 5 tahun 1960 tentang Peraturan Dasar Pokok-Pokok Agraria

Widyorini, N., C. A’in, S. Rudiyanti, Suryanti dan P. W. Purnomo. 2015. Program Pendampingan Kelompok Tani "Karya Mina Mandiri” Mangunharjo dalam Rangka Peningkatan Penjualan dan Promosi Produk Hasil Olahan Mangrove. Jurnal Saintek Perikanan. 10 (2): 125-128

Ziku, R. M. 2015. Partisipasi Masyarakat Desa Komodo dalam Pengembangan Ekowisata di Pulau Komodo. Jurnal Master Pariwisata. 2 (1): 1-21 